J. Product. \& Dev., 15(3):395-404 (2010)

\title{
CONTRIBUTION TO KNOWLEDGE OF SOME SOIL FUNGI IN EASTERN REGION, IN LIBYA
}

\author{
Abdalla M. A. Mansour \\ Plant Production Department, Faculty of Agriculture, Garyounis University, \\ Benghazi, Libya.
}

\begin{abstract}
:
Fifty nine species belonging to 23 genera were obtained from 100 soil samples collected from the eastern region in Libya. The most common genera and their species were Aspergillus (11 species), Cladosporium (5 species), Fusarium (5 species), Penicillium (10 species), and Rhizopus (1 species). The most abundant species were: Alternaria alternata, Aspergillus flavus, A. fumigatus, A. niger, A. ochraceus, A. Terreus, A. ustus, Cladosporium cladosporioides, Fusarium moniliforme, F. oxysporium, Penicillium chrysogenum, $P$. citrinum, Pleospora herbarum, and Rhizopus stolonifer.
\end{abstract}

Key words: Fungi, Soil, Libya

\section{INTRODUCTION:}

The soils represent the main reservoir of fungi and microorganisms. Some of these fungi are pathogens to both animal and human, and some of them cause plant diseases. Fungi perform important services related to water dynamics, and disease suppression. Along with bacteria, fungi are important as decomposers in the soil food web. They convert hard materials to digest organic material into forms that other organisms can use. Fungal hyphae can bind soil particles together, causing aggregation of soil particles and that helps increase water infiltration and soil holding capacity (Watanabe 2002).

Soil fungi can be classified into three groups based on their energy source. Decomposers (saprophytic fungi), Mutualist (Micorrhizal fungi), and Pathogenic (Parasitic fungi). No rigid definition of soil fungi is given but fungi detected or isolated from soil, seeds, and roots of plants (Watanabe 1977a, b, c; 1987; 1989, and Watanabe 1988) are tentatively termed as soil fungi. Isolated from plant residues in soil, soil borne animals, or mashrooms are also included as soil fungi (Watanabe 2002). Mycoflora of soils have 
been paid a considerable attention beginning from 1886. were Admetz (1886) was the pioneer of soil fungi study, isolating and naming 4 species of yeasts, 11 species of fungi including Aspergillus, Penicillium, and Mucor (Watanabe 2002).

Butler (1907) isolated 6 Pythium species in India. In Japan, Takahashi in 1919 isolated and identified 25 species belonging to 13 genera from field soils Komaba in Tokyo (Watanabe 2002). According to Burges (1965) more than 600 fungus species including over 200 Phycomycetous species, 32 Ascomycetous species, and 385 Deutromycetous species are recorded as soil fungi in the first edition of ( A Manual of Soil Fungi) written by Gilman in 1945.

Few investigations have been made of soil fungi in Libya. Naim (1976a and b) studied rhizosphere and soil fungi of Artemisia herba alba and fungus flora under citrus trees in Tripoli, Libya. Youssef (1974) studied the fungal flora of Libyan soil. El-Said and Saleem (2008) studied soil fungi at western region, Libya

This contribution aimed to study the distribution and occurrence of various groups of fungi in many kinds of soils (cultivated, desert, and saline soils) in eastern region of Libya.

\section{MATERIALS AND METHODS:}

\section{Cultures:}

100 soil samples $100 \mathrm{gm}$ for each collected from different sites and kinds of soil (cultivated, desert, saline soils) in the eastern region of Libya, spread over 10 location, by 10 isolates of sporadic and random for each site according to method described by Jonson and Curl (1972). The geographic area of study varied over a wide area from Ajdabiya at south to Benghazi and along the coastline of the Mediterranean Sea and the Green Mountain to Derna at the east (Figure 1). The samples were collected between August and April in 2008 and 2009 years.

Estimation of soil fungi: The dilution-plate method as described by Jonson and Curl (1972) was used for estimation of soil fungi. Modified Czapek's Dox agar medium was employed (g/l: glucose 10.0 or cellulose 20.0 , sodium nitrate 3.0, magnesium sulphate 0.5 , potassium chloride 0.5 , potassium dihydrogen phosphate 1.0, ferrous sulphate 0.01, agar 15). This media were supplemented with rose Bengal $(0.1 \mathrm{mg} / \mathrm{ml})$ and chloramphenicol $(0.05 \mathrm{mg} / \mathrm{ml})$ in order to suppress bacterial growth. The plates were incubated at $28^{\circ} \mathrm{C}$ for $5-10$ days during, which the developing fungi were counted. Identification of the isolated fungal 


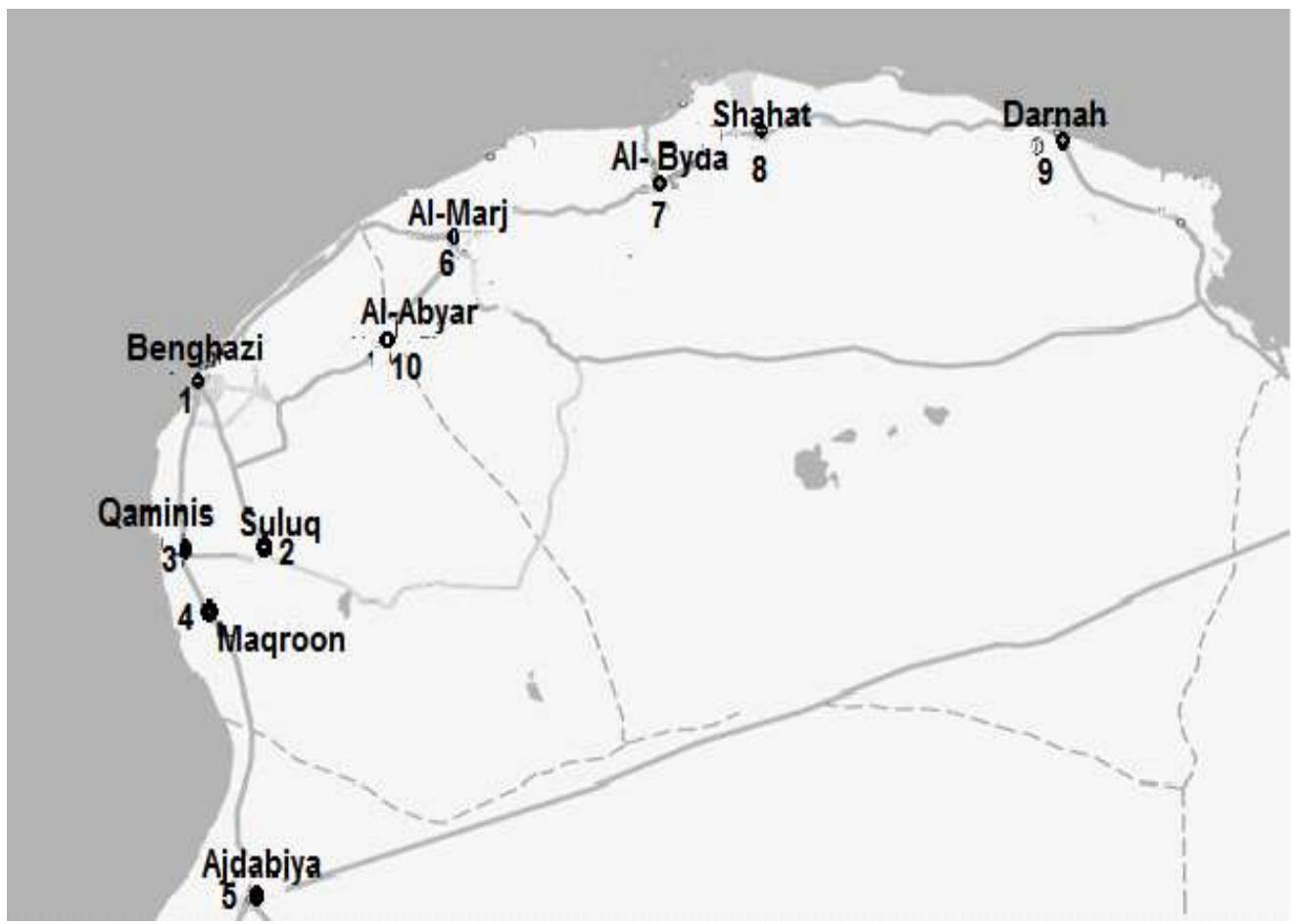

Figure 1: A map showing the different sites of the study in eastern region in Libya.

species was done using sterioscopic binuclear (40X) and compound research binuclear microscope (1000X).

Chemical analysis of soil samples: The amount of total soluble salts per 10 g oven-dry soil was calculated. A pH meter (digitalionalyser) used for determination of soil $\mathrm{pH}$. Carbonate, Bicarbonate, Calcium $(\mathrm{Ca}+2)$, and magnesium $(\mathrm{Mg}+2)$ were determined directly in the soil according to the method described by Jackson (1958), and by using of the kits of HANNA instruments Italy.

\section{RESULTS AND DISCUSSION}

The soil samples were tested for their water content which were varied between high dry soils with $0.1 \sim 0.3 \%$ and high wet soils with $15 \sim 20.5 \%$ occurred in some cultivated soils and in the rainy locations in the Green Mountain sites. Abol-Nasr (1981) found that the water content in soil samples collected from 
the red sea shore in Egypt was between 0.4 21\%, while Abdel-Sater (1987) found that the water content in soil samples collected from different habitats in Egypt fluctuated between $2.4 \sim 21.9 \%$. Naim (1976a and b) found the percentage of water content in sandy soil cultivated by Artemisia herba alba was between 7.3 $\sim 9.4 \%$, and $10.6 \sim 14.5 \%$ in soils under citrus trees respectively. Youssef (1974) found the water content of air - dry soil was $0.61 \sim 2.03 \%$.

The soil samples were poor in their organic matter content, where the planted soil was the richest, the saline soil was the poorest with the organic matter. Such results were agree with the results obtained from different type of soil in Arab countries (Moubasher et al., 1985; Abdel-Sater, 1987; Abdel-Hafez,1994; Abdel-Hafez et al., 1989a, b, 1990a, b, 1995; El-Said, 1994, El-Said and Saleem, 2008), El-Amin and Saadabi (2007) found soils of sugar estate slightly rich in organic matter content.

The value of total soluble salts was highest in saline soils (1 8.9\%). These values were not found in the cultivated and desert soils except in four samples collected from Ajdabiya and suluq. Youssef (1974) found that the total soluble salts in different localities in Libya ranged between $0.08 \sim 0.60$. Abdel-Sater (1987) found that the water content in soil samples collected from different soil type ranged between $0.13 \sim 18.63 \%$. Also, Abdel-Hafez et al., (1991, 1995) recorded that the total soluble salts fluctuated between $2.2 \sim 4.7 \%$ and $0.18 \sim$ $0.30 \%$. While El-Said (1994) reported a fluctuated value between $2.3 \sim 4.7 \%$ of total soluble salts in cultivated soil in Bahrain.

The amount of carbonates, bicarbonates, and chlorides in the samples tested fluctuated markedly from $0.01 \sim 7.05 \%$; $0.001 \sim 7.40 \%$; and $0.15 \sim 6.89 \%$, respectively. El-Said and Saleem (2008) recorded that the amount of carbonates, bicarbonates, and chlorides in the tested samples were $2.01 \sim 7.60 \%, 0.23 \sim 2.04 \%$ and $0.02 \sim 0.24 \% ; 3.21 \sim 7.75 \%, 0.32 \sim 2.02 \%$ and $0.001 \sim 0.32 \%$; and 6.09 $\sim 7.49 \%, 0.18 \sim 1.72 \%$ and $0.02 \sim 1.31 \%$ in cultivated, desert and saline soils, respectively. Abdel-Sater (1987) recorded that their amount in soils collected from Egypt ranged between $2.26 \sim 5.4 \%, 0.36 \sim 1.5 \%$ and $0.07 \sim 0.68 \% ; 1.65 \sim 5.88 \%$, $0.23 \sim 1.02 \%$ and $0.14 \sim 3.9 \%$; and $4.2 \sim 5.94 \%, 0.18 \sim 1.93 \%$ and $0.36 \sim 4.14 \%$, respectively.

The amount of mineral elements in the soil samples were: Ca: 0.02 3.85mg; Mg: $0.02 \sim 1.00 \mathrm{mg}$. Abdel-Sater (1987) found that the amount of elements in soils collected from Egypt were: Ca: $0.03 \sim 0.75,0.03 \sim 2.67$ and 0.07 $\sim 3.75 \mathrm{mg}$; Mg: $0.13 \sim 0.54,0.02 \sim 0.54$ and $0.013 \sim 1.23 \mathrm{mg}$ in cultivated, desert and saline soils, respectively.

Values of $\mathrm{pH}$ were fluctuated between $7.1 \sim 8.2$ in the most studied localities except five localities were reaches 4.6, 5.1 and 6.4. Youssef (1974) 
found the $\mathrm{pH}$ values ranged between $7.1 \sim 8.1$, Naim $(1976 \mathrm{a}$ and $\mathrm{b}$ ) found values ranged between $6.6 \sim 7.2 ; 6.8 \sim 7.4$ respectively. El-Said and Saleem (2008) found that the $\mathrm{pH}$ values of cultivated, desert and saline soils gathered from western region of Libya fluctuated between $4.5 \sim 7,6.4 \sim 7.2$ and $6.4 \sim 7.3$, respectively. Abdel-Sater (1987) observed that values fluctuated between $7.2 \sim 8.9,6.9 \sim 7.4$ and $7.2 \sim 8.8$ in cultivated, desert and saline soils gathered from Egypt, respectively. Similar observations were obtained by Abdel-Hafez et al. (1989b, 1991, and 1995) and by El-Said (1994).

Fifty-nine fungal species belonging to 23 genera collected from 100 samples (Table 1). These genera identified by using many references. [Pictorial atlas of soil and seed fungi (Watanabe, 2002), soil fungi in Qatar and other Arab countries (Moubasher, 1993), Compendium of soil fungi (Domsch and Gams, 1980), a laboratory guide to common Penicillium species (Pitt, 1985), the genus Fusarium (Booth, 1971 and 1977), the genus Aspergillus (Raper and Fennell, 1965), and a manual of the Penicillium (Raper and Thom, 1949)].

The most common genera were Aspergillus (11 species), Cladosporium (5 species), Fusarium (5 species), Penicillium (10 species), and Rhizopus (1 species). The most abundant species were: Alternaria alternata, Aspergillus flavus, A. fumigatus, A. niger, A. ochraceus, A. terreus, A. ustus, Cladosporium cladosporioides, Fusarium moniliforme, F. oxysporium, Penicillium chrysogenum, P. citrinum, Pleospora herbarum, and Rhizopus stolonifer. These species isolated with different numbers from many kind of soils from many localities in the world by many workers (Abdel-Hafez et al.1990a; Abdel-Hafez, 1994; Moubasher and Mazen, 1991; Moubasher and Abdel-Hafez, 1978; Lalley and viles, 2005; Saadabi, 2006; and El-Said and Saleem, 2008). Abdel-Sater (1987) found that Aspergillus, Penicillium, and Fusarium were the broadest genera isolated from 25 cultivated and desert soil samples. Abol-Nasr (1981) found that Aspergillus niger, A. fumigatus, and Penicillium notatum the commonest species in red sea shore soils. El-Said and Saleem, (2008) found that the most prevalent species in western region in Libya from three types of soils on three types of media were: Alternaria alternata, Aspergillus flavus, A. fumigatus, A. niger, A. terreus, Emericella nidulance, Fusarium oxysporium, Mycosphaerella tassiana, Nectria haematococca and Penicillium chrysogenum. 
Table 1: Total fungal species and genera obtained from 100 soil samples collected from 10 Localities in eastern region of Libya.

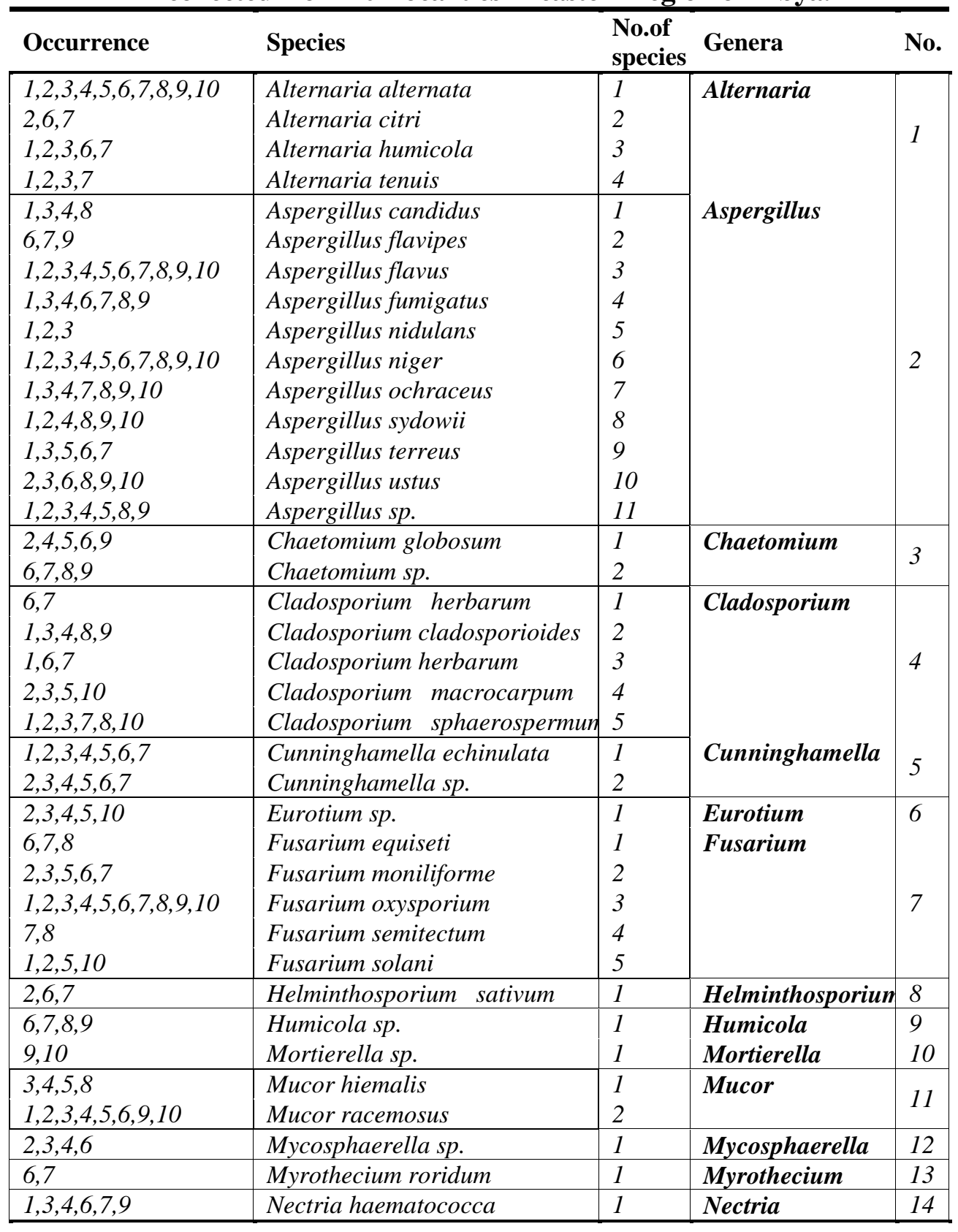




\begin{tabular}{|c|c|c|c|c|}
\hline 8,9 & Penicillium canescens & $\overline{1}$ & Penicillium & 15 \\
\hline $1,9,10$ & Penicillium chrysogenum & 2 & & \\
\hline $2,3,4,6,8$ & Penicillium citrinum & 3 & & \\
\hline 9 & Penicillium cyclopium & 4 & & \\
\hline 8,9 & Penicillium decumbens & 5 & & \\
\hline $1,3,6,7$ & Penicillium digitatum & 6 & & \\
\hline 9 & Penicillium frequentans & 7 & & \\
\hline $3,4,5,10$ & Penicillium funiclusum & 8 & & \\
\hline 6,7 & Penicillium lilacinum & 9 & & \\
\hline $3,8,9$ & Penicillium thomii & 10 & & \\
\hline 9 & Phoma exigua & 1 & Phoma & \\
\hline $1,2,3,8,9$ & Phoma glomerata & 2 & & 16 \\
\hline 10 & Phoma sp. & 3 & & \\
\hline $1,6,7$ & Phytophthora sp. & 1 & Phytophthora & 17 \\
\hline $1,2,4,5,6,8,10$ & Pleospora herbarum & 1 & Pleospora & 18 \\
\hline 1,6 & Rhizoctonia solani & 1 & Rhizoctonia & 19 \\
\hline $1,2,3,4,5,6,7,8,9,10$ & Rhizopus stolonifer & 1 & Rhizopus & 20 \\
\hline $1,7,8,9$ & Trichoderma viride & 1 & Trichoderma & 21 \\
\hline 9 & Trimmatostroma sp. & 1 & Trimmatostroma & 22 \\
\hline $8,9,10$ & Ulocladium atrum & 1 & Ulocladium & 22 \\
\hline $1,2,3,4,5,7,9$ & Ulocladium botrytis & 2 & & 23 \\
\hline
\end{tabular}

1. = Benghazi; 2. = Suluq; 3. = Qaminis; 4. = Maqroon; 5. =Ajdabiya; 6. = Al-Marj; 7. = Al-Byda; $\quad 8 .=$ Shahat; 9. = Darnah; 10. = Al-Abyar.

\section{REFERENCES:}

Abdel-Hafez, S. I. I. 1994. Studies on soil mycoflora of desert soils in Saudi Arabia. Mycopathologia, 80:3-8.

Abdel-Hafez, A. I. I., Abdel-Hafez, S. I. I., Mohawed, S. M. and Ahmed, T. A. M. 1990a. Seasonal fluctuations of soil and air borne fungi at Qena, Upper Egypt. Bull. Fac. Sci., Assiut Univ.,19:47-63.

Abdel-Hafez, A. I. I., Abdel-Hafez, S. I. I., Mohawed, S. M. and El-Said, A. H. M. 1991. Composition, occurrence and cellulolytic activities of fungi in habiting soils along Idfu-Marsa Alam road at Eastern desert, Egypt. Bull. Fac. Sci. Assiut Univ., 20:21-48.

Abdel-Hafez, A. I. I., Mazen, M. B. and Galal, A. A. 1989a. Some ecological studies of osmophilic and halophilic soil fungi of Sinai peninsula, Egypt. Sohag Pure and Appl. Sci. Bull. Fac. Sci. Egypt, 5:67-83. 
Abdel-Hafez, A. I. I., Mazen, M. B. and Galal, A. A. 1990b. Glycophilic and cellulose-decomposing fungi from soils of Sinai, Peninsula, Egypt. Arab Gulf J. Scient. Res., 8:153-168.

Abdel-Hafez, S. I. I., El-Said, A. H. M. and Gherabawy, Y. A. M. H. 1995. Mycoflora of leaf surface, stem, bagasse and juice of adult sugarcane (Saccharum officinarum L.) Plant and cellulolytic ability in Egypt. Bull. Fac. Sci., Assiut Univ., 24:113-130.

Abdel-Hafez, S. I. I., Mohawed, S. M. and El-Said, A. H. M. 1989b. Soil mycoflora of Wadi Qena in eastern desert of Egypt. Bull. Fac., Sci., Qena, Egypt, 1:77-93.

Abdel-Sater, M. A. 1987. Ecological and physiological studies on halophilic fungi in Egypt. M.Sc. Thesis, Botany Department, Faculty of Science, Assiut University, Egypt.

Abol-Nasr, M. B. M. 1981. Study on soil fungi of the Red Sea Shore. M.Sc. Thesis, Botany Department, Faculty of Science, Assiut University, Egypt.

Adametz, L. 1886. Untersuchungen über die niederen Pilze der Ackerkrume. Inaug.Diss., 1-78. Leipzig.

Booth, C. 1971. The genus Fusarium. Commonwealth Mycological Institute, Kew, Surrey, England. PP: 237.

Booth, C. 1977. Fusarium laboratory guide to the identification of the major species. Commonwealth Mycological Institute, Kew, Surrey, England. PP: 58.

Burges, A. 1965. The soil microflora - its nature and biology in Baker, K. F. and Snyder, W. C. (Eds). Ecology of Soil-Borne Plant Pathogens. Prelude to Biological Control. University of California Press, Berkeley. PP: 21-32.

Butler, E. J. 1907. An account of the genus Pythium and some Chytridiaceae. Mem. Dept. Agric. India, 1:1-160.

Domsch, K. H. and Gams, W.1980. Compendium of soil fungi. Academic Press. PP: 859

El-Buni, A. M. and Rattan, S. S.1981. Chek list of Libyan fungi, Botany Dept. Fac. Sci., Al-Faateh University, Libyia.

El-Said, A. H. M. 1994. Studies on soil mycoflora of Bahreen. Microbiol. Res. 149:263-269.

El-Said, A. H. M. and Saleem, A. 2008. Ecological and physiological studies on soil fungi at western region, Libya. Mycobiology,36(1): 1-9

El-Amin, A. and Saadabi, A. M. A. 2007. Contribution to the knowledge of soil fungi in Sudan Rhizosphere mycoflora of sugarcane at Kenana Sugar Estate. Inter. J. of Botany, 3(1): 97-102. 
Gilman, J. C. 1945. A Manual of Soil Fungi. The Collegiate Press, Ames, IA.PP: 392.

Jackson, M. L. 1958. Soil Chemical Analysis. Constable Publisher, London.

Johnson, L. F., and Curl, E. A. 1972. Methods for Research on the Ecology of Soil- Borne Pathogens. Burgress Publ. Co. Minneapolis, Minnesota. PP: 247

Lalley, J. S. and Viles, H. A. 2005. Terricolous lichens in the northern Namib desert of Namibia: distribution and community composition. Lichenologist, 37: 77-91

Moubasher, A. H. 1993. Soil fungi in Qatar and other Arab Countries. Center of Scientific and Applied Research, University of Qatar, Qatar, PP: 566.

Moubasher, A. H. and Abdel-Hafez, S. I. I. 1978. Studies on the mycoflora of Egyptian soils. Mycopathologia, 63(1): 3-10.

Moubasher, A. H., Abdel-Hafez, S. I. I. and El-Maghraby, O. M. O. 1985. Studies on soil mycoflora of Wadi Bir-El-Ain, Eastern Desert, Egypt. Cryptogamie Mycologie, 6:129-143.

Moubasher, A. H. and Mazen, M. B. 1991. Assay of cellulolytic activity of cellulose-decomposing fungi isolated from Egyptian soils. J. Basic Microbiol., 31:59-68.

Naim, M. S. 1976a. Contribution to the knowledge of soil fungi in Libya. I. Rhizosphere and soil fungi of Artemisia herba alba in Tripoli. Mycopath. Mycol. Appl. , 31: 296-299.

Naim, M. S. 1976b. Contribution to the knowledge of soil fungi in Libya. II. Fungus flora under Citrus trees in Libya. Mycopath. Mycol. Appl., 31: 296-299.

Pitt, J. I. 1985. A laboratory guide to common Penicillium species. Commonwealth Scientific and Industrial Research Organization Division of Food Research, PP:184

Raper, K. B. and Fennell, D. J. 1965. The genus Aspergillus. Williams and Wilkins, Baltimore, U.S.A. PP: 686.

Raper, K. B. and Thom, C. 1949. A manual of Penicillium. Williams and Wilkins, Baltimore, U.S.A. PP: 875.

Saadabi, A. M. A. 2006. On the fungal flora of Saudi Arabian soils. Res. J. Microbiol., 1(3): 280-284.

Watanabe, T. 1977a. Pathogenicity of Pythium myriotylum isolated from strawberry roots in Japan. Ann. Phytopathol. Soc. Jpn., 43:306-309.

Watanabe, T. 1977b. A new species of Umbelopsis from strawberry roots. Trans. Mycol. Soc. Jpn., 18:242-244. 
Watanabe, T. 1977c. Fungi associated with strawberry roots in Japan. Trans. Mycol. Soc. Jpn., 18:251-256.

Watanabe, T. 1987. Plectospira myriandra, a rediscovered water mold in Japanese soil. Mycologia, 79:77-81.

Watanabe, T. 1989. Three species of Sordaria, and Eudarluca biconica from cherry seeds. Trans. Mycol. Soc. Jpn. 30:395-400.

Watanabe, T. 2002. Pictorial Atlas of Soil and Seed Fungi, Morphologies of Cultured Fungi and Key to Species. $2^{\text {nd }}$ Edition. CRC Press.

Watanabe, T., Uematsu, S., and Inoue, Y. 1988. Pathogenicity of twenty-three Pythium isolates from soils of Shikoku Island. Trans. Mycol. Soc. Jpn., 54:565-570.

Youssef, Y.A. 1974. On the fungal flora of Libyan soils. Arch. Microbiol., 99:167-171

$$
\begin{aligned}
& \text { مساهمة في معرفة بعض فطريات التربة في المنطقة الشرقية من ليبيا }
\end{aligned}
$$

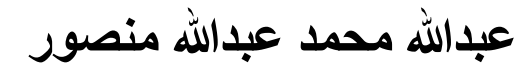

$$
\begin{aligned}
& \text { قسم الانتاج النباتي - كلية الزر اعة - جامعة قاريونس- بنغازي- ليبيا. }
\end{aligned}
$$



اخذت من المنطقة الثرقية في ليييا، كان من اكثر الاجناس تواجيا تلندا جنس Aspergillus

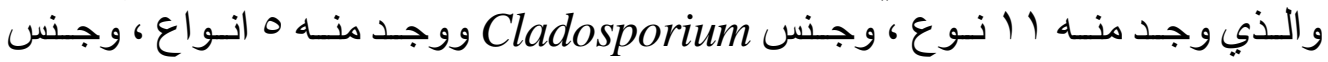

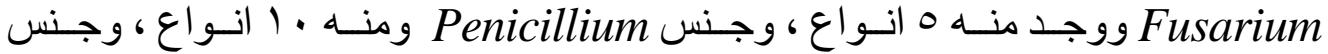

$$
\text { Rhizopus }
$$

Aspergillus flavus, ،Alternaria alternata ما اكثر الانواع كثافة فكانت ustus, .terreus, A.ochraceus, A.niger, A.fumigatus, A.A .Fusarium moniliforme, $F$ 'Cladosporium cladosporioides citrinum, Pleospora .oxysporium, Penicillium chrysogenum, $P$ Rhizopus stolonifer and cherbarum 